\title{
NEW FORM OF EQUATION FOR DEFORMATION RESISTANCE PREDICTION UNDER HOT ROLLING INDUSTRIAL CONDITIONS
}

\author{
Received - Primljeno: 2002-06-24 \\ Accepted - Prihvaćeno: 2002-09-15 \\ Preliminary Note - Prethodno priopćenje
}

\begin{abstract}
A new equation for the prediction of steel deformation resistance under industrial hot rolling conditions is proposed. This new expression can be used for more accurate description of material deformation behavior at service conditions utilizing data from laboratory plastometer experiments.
\end{abstract}

Keywords: steels; hot rolling; recrystallisation and recovery

Novi oblik jednadžbe za izračunavanje otpora deformacije u industrijskim uvjetima toplog valjanja. Predlaže se nova jednadžba za izračunavanje otpora deformacije čelika u industrijskim uvjetima toplog valjanja. Novi izraz se može koristiti za točniji opis deformacije materijala u radnim uvjetima za što se koriste podaci dobiveni laboratorijskim eksperimentima s plastometrom.

Ključne riječi: čelici, toplo valjanje, rekristalizacija i oporavak

\section{INTRODUCTION}

A variety of laboratory plastometer experiments are used to investigate the plastic deformation of materials. Of those probably the most powerful and promising, but at the same time relatively simple, for investigating steel and predicting its behavior under hot rolling service conditions, are the torsion plastometer test [1-5] and the compression plastometer test, utilizing either ordinary compression [6-8] or stress relaxation methods [9-11].

There are several modifications of the above-mentioned methods performed according to the different time-temperature schedules: isothermal or anisothermal; continuous (one step) deformation or different sequences of repeated deformation. The final goal of all of these tests should be to predict the deformation resistance of the steels under actual industrial conditions. Among the variables that influence hot deformation (strain, strain rate, temperature and "input" grain size), due to constructional restrictions of plastometers, the strain rate in laboratory tests is very often one or more orders of magnitude lower than typical rates on industry rolling mills. Thus, although an appropriate description of the hardening/softening process kinetics can be obtained under laboratory conditions, the predicted stress values and the ones in the material pro-

M. Dzubinsky, Swinden Technology Centre, Corus group, Moorgate, Rotherham, United Kingdom, F. Kovac, A. Petercakova, Institute of Materials Research of Slovak Academy of Sciences, Košice, Slovakia cessed in an industrial rolling mill are usually different. Also it is likely that kinetics of recovery/recrystallisation at repeated deformation with service strain rates will be different compared with the same process kinetics during the laboratory experiments because of different stored energy of plastic deformation as the sequence of mentioned difference in strain rates.

The value of stress at the same strain and temperature is higher at higher strain rates. This is because the amount of restoration caused by dynamic recovery decreases as the strain rate increases. At lower strain rates, the level of restoration is higher than the result of longer deformation time [12]. Generally, higher strain rates change the form of the stress-strain curve shifting the peak of the stress-strain curve upwards and to the right, making the curve flatter. In extreme conditions, the steel can fracture before the stress achieves the "theoretical" stress peak, i.e. before the start of dynamic recrystallisation (DRX). Different stress levels at the same strain and temperature, corresponding to the different strain rates, change the kinetics of dynamic recovery and DRX as well as the kinetics of "post deformation processes" such as static recovery, static recrystallisation (SRX) or metadynamic recrystallisation (MDRX).

There are few studies of the influence of strain rate on the kinetics of SRX and MDRX processes [13-20]. With the aim of predicting steel behavior under industrial hot working conditions, two types of correction of laboratory result are proposed: (i) interpass time correction; (ii) correction of stress value. 
Considering the applied time-temperature deformation schedule for different hot working processes, we can expect the occurrence of DRX and subsequently MDRX at a certain stage of wire rod rolling as a result of high strain rates of $10-1000 \mathrm{~s}^{-1}$ and short times of $0.01-1 \mathrm{~s}$ between passes in this process.

The hot rolling process has to be considered as consisting of two distinct stages: roughing and finishing. Roughing is characterized by higher temperatures (1200 $\left.1000^{\circ} \mathrm{C}\right)$, relatively low strain rates $\left(1-20 \mathrm{~s}^{-1}\right)$ and long interpass times $(10-50 \mathrm{~s})$. Whereas lower temperatures $\left(1000-650{ }^{\circ} \mathrm{C}\right)$, high strain rates $\left(10-200 \mathrm{~s}^{-1}\right)$ and short breaks between passes ( 0.4 - $4 \mathrm{~s})$ are typical for finishing [13]. Usually during roughing the material is fully recrystallised between passes, regardless of which kind of recrystallisation occurs - SRX or MDRX. During finishing the situation is more complicated. The short interpass times and continuous temperature reduction lead to strain accumulation. Between passes we can expect either static recovery or MDRX. Generally, the kinetics of MDRX is much more sensitive to the strain rate than kinetics of SRX [13]. However, in the case of high strain rate and short times between deformations, more interpass softening takes place industrially for a given interpass time. Therefore, it is necessary to correct the laboratory interpass times. Allowances can be made for this effect by using the following "law of similarity" for MDRX $[14,16]$ :

$$
t_{\text {tab }}=t_{\text {mill }}\left(\frac{\dot{\varepsilon}_{\text {mill }}}{\dot{\varepsilon}_{\text {lab }}}\right)^{n}
$$

where

the exponent $n$ is in the range $0.5<n<1.1$,

$t$ - interpass time,

$\dot{\varepsilon}$ - strain rate, subscripts ${ }_{\text {lab }}$ and ${ }_{\text {mill }}$ correspond to laboratory and service rolling values, respectively.

In order to determine the deformation resistance of steel that would be expected during each pass on a rolling mill, it is necessary to apply a strain rate correction for the mean flow stress $\bar{\sigma}$ (or MFS) [17]:

$$
\bar{\sigma}_{\text {mill }}=\bar{\sigma}_{l a b}\left(\frac{\dot{\varepsilon}_{\text {mill }}}{\dot{\varepsilon}_{\text {lab }}}\right)^{p}
$$

Equation (2) is evaluated from the common relationship that describes the flow stress in the material [18]:

$$
\sigma=\sigma_{0} \varepsilon^{m} \cdot \dot{\varepsilon}^{p} \cdot \exp (A / T)
$$

where

$\sigma_{0}$ and $A$ are material constants, $m$ - strain,

$p$ - strain rate exponents for the flow stress.

According to [17], $p^{\prime}$ is a constant $\left(p=p^{\prime} \times T\right)$ and has value of $4.85 \times 10^{-5}$ and $8.91 \times 10^{-5}$ for the austenitic and ferritic regions, respectively.

The authors of [15] claim $p=0.12$ for the conditions of their experiment. However, if it is assumed that equation (3) describes the flow stress curve correctly, then the two stress-strain curves resulting from different applied strain rates should simply be displayed vertically up the stress axis, i.e. have the same shape. Hence, characteristic points like the peak stress (PS) or yield point should be at the same strain, which is at variance with observed behavior. Therefore equation (3) and its derivate equation (2) are only first approximations for predicting the flow stress curve under service condition. To get more accurate prediction of MFS, it is necessary to take into account this "curve shape" factor.

The authors of [19] underline the fact that equation (2) is relevant only at strain values of $\varepsilon \leq 0.4$. At higher strain values, it seems to be necessary to take into account an effect of dynamic softening process. For this purpose, a modified equation is proposed [1]:

$$
\sigma=A \cdot \varepsilon^{B} \cdot \exp \left(-B \cdot \frac{\varepsilon}{\varepsilon^{p}}\right) \cdot \dot{\varepsilon}^{\left(D-\frac{F}{T}\right)} \exp (-H \cdot T)
$$

where

$A, B, S, D, F$ and $H$ are material constants, $\varepsilon_{p}$ is the peak strain and $\varepsilon_{p}=f\left(\dot{\varepsilon}, Q, T_{d}\right)$, where $Q$ is activation energy of dynamic recrystallisation.

For the steel investigated in [20], $p$ is given by the following equation in the both austenitic and ferritic regions:

$$
p=\varepsilon^{-0.173} \cdot T_{m i l l}^{-0.987} \cdot \dot{\varepsilon}_{m i l l}^{-0.1964}
$$

However, the latter equation is valid only for the particular steel composition and its physical basis is not clear.

As shown above, current methods of predicting steel deformation resistance in industrial rolling mills have some restrictions and are not generally applicable. Moreover, the "basic" equation (3) for flow stress approximation is not optimal. In the present work a new form of equation (2) and as a consequence a new form of the strain rate coefficient $p$ are proposed. 


\section{EXPERIMENTAL PROCEDURE}

The chemical composition of the steel used for current investigation was as follows (in wt. \%): $\mathrm{C}=0.08, \mathrm{Mn}=$ $1.72, \mathrm{Si}=0.06, \mathrm{P}=0.013, \mathrm{~S}=0.005, \mathrm{Al}=0.047, \mathrm{Cu}=$ $0.008, \mathrm{Ni}=0.013, \mathrm{Cr}=0.015, \mathrm{Mo}=0.011, \mathrm{Nb}=0.054$, $\mathrm{V}=0.077, \mathrm{Ti}=0.029$. Bars with the following dimensions, 20x20x220 mm, were cut up from slabs and than homogenized at $1200{ }^{\circ} \mathrm{C}$ in a vacuum furnace. Samples with gauge length $50 \mathrm{~mm}$ and diameter $6 \mathrm{~mm}$ were subsequently machined from the annealed bars. The plastometer program was carried out on a SETARAM torsion plastometer and consisted of simple (single step) deformation tests (ST), anisothermal interrupted tests (AIT) and simulation tests. In all the plastometer tests, samples were austenised at 1200 ${ }^{\circ} \mathrm{C}$ for $10 \mathrm{~min}$ before deformation (first deformation at AIT and simulation) and then cooled to the deformation temperature. ST were carried out at $T=\{1200 ; 1150 ; 1050$, $\left.\ldots, 750,700{ }^{\circ} \mathrm{C}\right\}$, samples were deformed up to $\varepsilon=1$, at two strain rates, $\dot{\varepsilon}=0.045 \mathrm{~s}^{-1}$ and $\dot{\varepsilon}=0.45 \mathrm{~s}^{-1}$. Additionally, the ST were performed at $T=1050{ }^{\circ} \mathrm{C}$ with strain rates of $\dot{\varepsilon}=1.8 \mathrm{~s}^{-1}$ and $\dot{\varepsilon}=3.6 \mathrm{~s}^{-1}$.

AIT were intended to establish $T_{n r}$. Strain $\varepsilon=0.24$ and strain rate $\dot{\varepsilon}=0.45 \mathrm{~s}^{-1}$ were applied at each deformation, the interpass time was $10 \mathrm{~s}$, and the sample cooling rate was constant at $3{ }^{\circ} \mathrm{C} / \mathrm{s}$. Three AIT series were performed with a different temperature for the first deformation. These series covered the temperature range of $1140-630{ }^{\circ} \mathrm{C}$.

Simulation tests were carried out using the strain/ interpass time conditions typical for industrial hot rolling schedule (see Table 1.), but each deformation was performed with the same strain rate, i. e. $\dot{\varepsilon}=0.45 \mathrm{~s}^{-1}$. Several simulations were carried out according to different temperature schedules in the temperature range of $1200-700{ }^{\circ} \mathrm{C}$.

Table 1. Typical industrial hot rolling schedule

Tablica 1. Tipičan plan valjanja

\begin{tabular}{|l|c|c|c|c|c|c|c|}
\hline Number of mill & 1 & 2 & 3 & 4 & 5 & 6 & 7 \\
\hline True strain & 0.33 & 0.45 & 0.54 & 0.48 & 0.51 & 0.57 & 0.43 \\
\hline Time to next pass [s] & 12.2 & 25.7 & 21.0 & 15.2 & 43.8 & 3.00 & 2.10 \\
\hline Number of mill & 8 & 9 & 10 & 11 & 12 & 13 & 14 \\
\hline True strain & 0.54 & 0.51 & 0.38 & 0.35 & 0.26 & 0.15 & - \\
\hline Time to next pass [s] & 2.10 & 1.50 & 1.20 & 0.90 & 0.80 & - & - \\
\hline
\end{tabular}

\section{RESULTS AND DISCUSSION}

It is evident from the ST and AIT series, that the $\mathrm{Ar}_{3}$ temperature of the investigated steel is about $750{ }^{\circ} \mathrm{C}$. For the estimation of no-recrystallisation temperature $T_{n r}$ the " $\sigma_{0.05}$ criteria" [21] were used. In Figure 1., the $\sigma_{0.05}$ values at $\varepsilon=0.05$ from both AIT and ST series are compared. It is obvious that, below $T \cong 980^{\circ} \mathrm{C}$, the steel is not fully softened during the interpass breaks, i. e. for this steel $T_{n r}=980^{\circ} \mathrm{C}$.

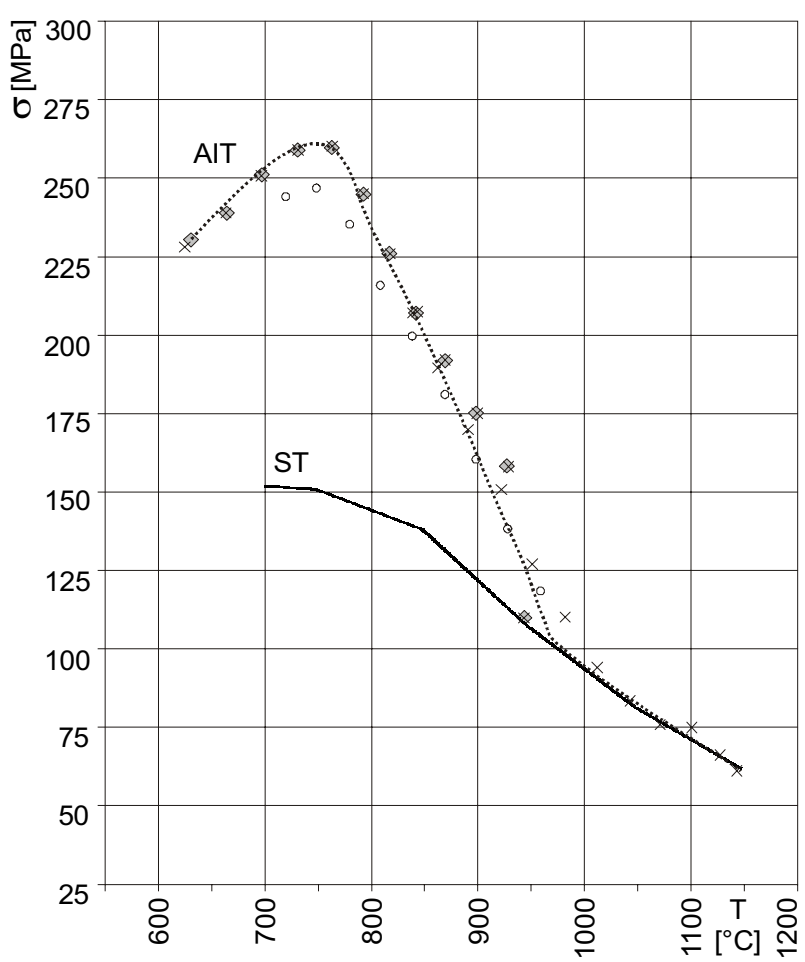

Figure 1. The $\sigma_{0.05}$ values at $\varepsilon=\mathbf{0 . 0 5}$ from both AIT and ST series are compared

Slika 1. Uspoređivanje vrijednosti $\sigma_{0.05}$ pri $\varepsilon=0.05$ iz serije AIT i ST

In Figure 2., the dependencies of $p$ on $T$ and $\dot{\varepsilon}_{2} / \dot{\varepsilon}_{1}$ (this is considered to be equivalent to the mill/lab comparison, $\mathrm{i}$. e. $\dot{\varepsilon}_{\text {mill }}=\dot{\varepsilon}_{2}, \dot{\varepsilon}_{\text {lab }}=\dot{\varepsilon}_{1}$ ) are shown, which were calculated from the ST results utilising equation (2) and either the MFS

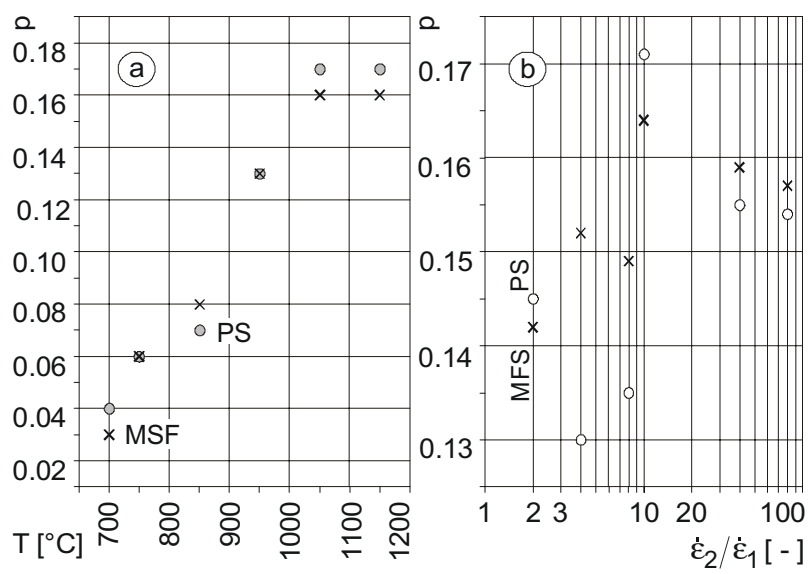

Figure 2. The dependencies of $p$ and $\dot{\varepsilon}_{2} / \dot{\varepsilon}_{1}$ on $T$

Slika 2. Ovisnost $p$ i $\dot{\varepsilon}_{2} / \dot{\varepsilon}_{1}$ oT

at a strain value of 1.0 or the PS value. It is obvious, that the value of $p$ is not constant and depends on both temperature and strain rate ratio. The dependency $p=p(T)$ has functional character and $p=p\left(\dot{\varepsilon}_{2} / \dot{\varepsilon}_{1}\right)$ is random. The form of equation (2) was altered to take into account the "curve shape" factor mentioned in the introduction: 
$\bar{\sigma}_{2}=\left(\bar{\sigma}_{1} \frac{\dot{\varepsilon}_{2}}{\dot{\varepsilon}_{1}}\right)^{p}$

Figure 3. shows the dependencies $p=p(T)$ and $p=$ $p\left(\dot{\varepsilon}_{2} / \dot{\varepsilon}_{1}\right)$ based on equation (6). In this case, contrary to the previous one, the dependency $p=p\left(\dot{\varepsilon}_{2} / \dot{\varepsilon}_{1}\right)$ is func-

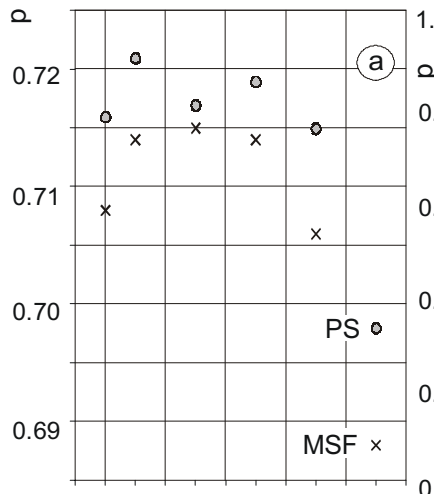

$\mathrm{T}\left[{ }^{\circ} \mathrm{C}\right] \stackrel{\circ}{\circ}$ \& \&

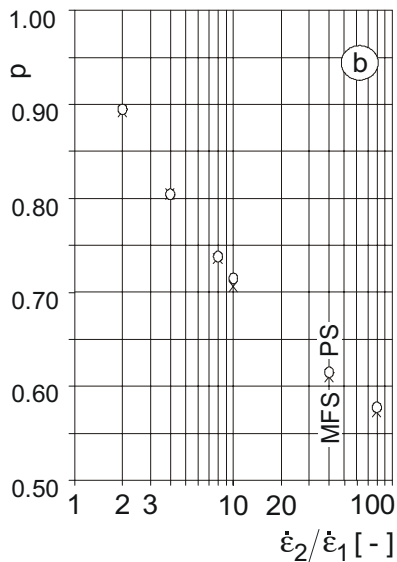

Figure 3. The dependencies $p=p(T)$ and $p=p\left(\varepsilon_{2} / \varepsilon_{1}\right)$ based on equation (6)

Slika 3. Ovisnost $\boldsymbol{p}=\boldsymbol{p}(\boldsymbol{T})$ i $\boldsymbol{p}=\boldsymbol{p}\left(\dot{\varepsilon}_{2} / \dot{\varepsilon}_{1}\right)$ temeljena na jednadžbi (6)

tional and $p=p(T)$ is random. Hence, it is necessary to modify equation (6) in a similar way to that in Ref. [17]. By substituting $p=p^{\prime} \times T$, the new equation is:

$\bar{\sigma}_{2}=\left(\bar{\sigma}_{1} \frac{\dot{\varepsilon}_{2}}{\dot{\varepsilon}_{1}}\right)^{p^{\prime} T}$

In Figure 4., the dependencies $p^{\prime}=p^{\prime}(T)$ and $p^{\prime}=$ $p\left(\dot{\varepsilon}_{2} / \dot{\varepsilon}_{1}\right)$ evaluated utilizing equation (7) are shown. In this
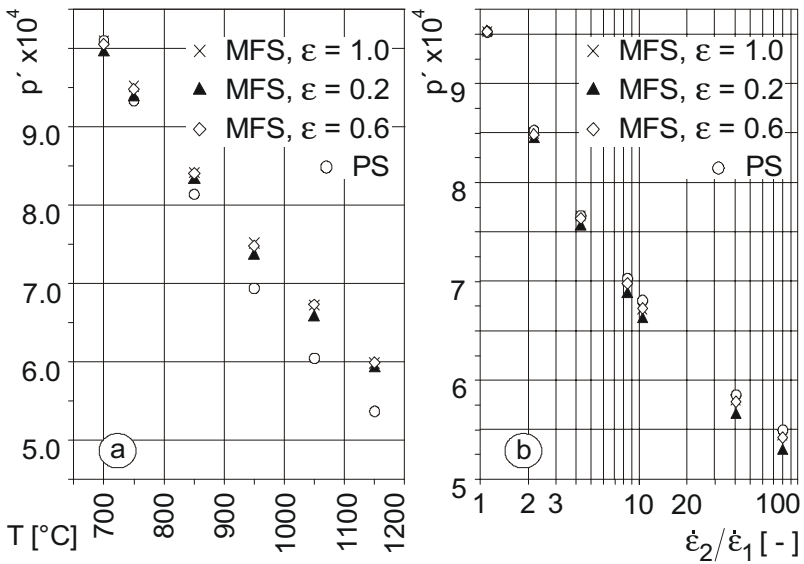

Figure 4. The dependencies $p^{\prime}=p^{\prime}(T)$ and $p^{\prime}=p^{\prime}\left(\dot{\varepsilon}_{2} / \dot{\varepsilon}_{1}\right)$ evaluated utilising equation (7)

Slika 4. Ovisnost $\boldsymbol{p}^{\prime}=\boldsymbol{p}^{\prime}(\boldsymbol{T})$ i $\boldsymbol{p}^{\prime}=\boldsymbol{p}^{\prime}\left(\xi_{2} / \varepsilon_{1}\right)$ procijenjena korištenjem jednadžbe (7) case, $p^{\prime}$ is calculated for MFS at different strain values: 1.0, 0.2 and 0.6 . The last two values were chosen because they define the range of applied strain during industrial rolling (see Table 1.). If equation (7) is used, dependencies $p^{\prime}=$ $p^{\prime}(T)$ and $p^{\prime}=p^{\prime}\left(\dot{\varepsilon}_{2} / \dot{\varepsilon}_{1}\right)$ have strict functional character in

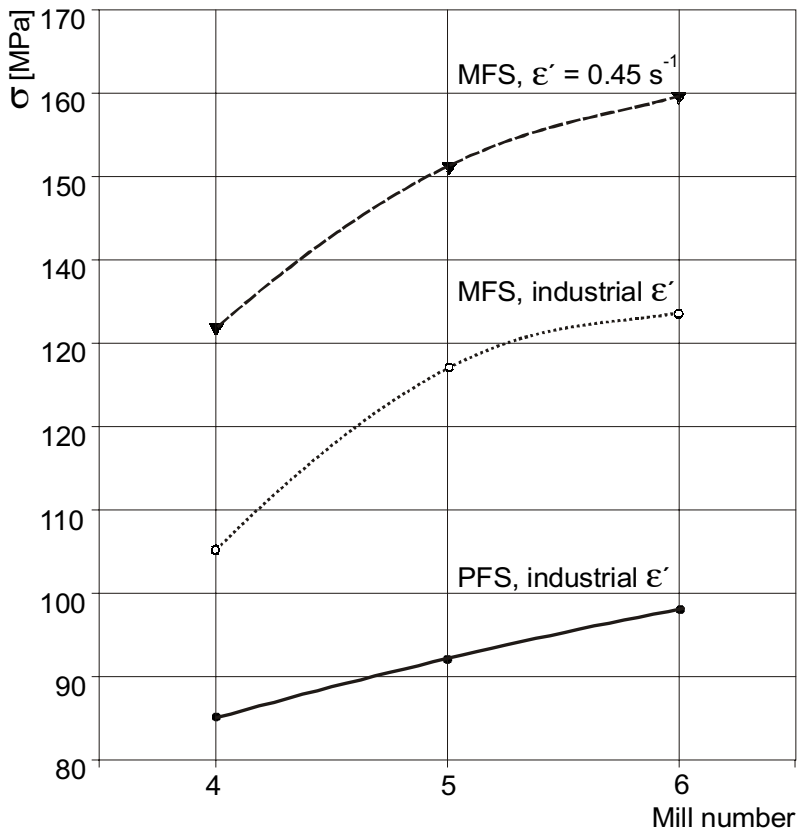

Figure 5. The results of the deformation resistance prediction for the investigated steel, under industrial hot rolling conditions, utilising data from the laboratory plastometer experiments and equations (7-9)

Slika 5. Rezultati izračunavanja otpora deformacije za istraživani čelik u uvjetima industrijskog toplog valjanja izračunati podacima dobivenim laboratorijskim ispitivanjem plastometra i jednadžbi (7 - 9)

both the austenite and two-phase regions, and the spread of $p$ ' values due to different strain levels is negligible. Moreover, it is possible to predict with good accuracy MFS as well as PS values at "higher" (mill) strain rate values utilizing the results of experiments at "lower" (experimental) ones. For the steel under investigation the following particular functional dependencies of $p^{\prime}$ on $T$ at $\dot{\varepsilon}_{2} / \dot{\varepsilon}_{1}=10$ and on $\dot{\varepsilon}_{2} / \dot{\varepsilon}_{1}$ ratio at $T=1050{ }^{\circ} \mathrm{C}$ were obtained:

$$
\begin{aligned}
& p^{\prime} \times 10^{4}=1.61+8.48 \times \exp \left(-\frac{T-700}{545}\right) \\
& p^{\prime} \times 10^{4}=5.24+2.31 \times \exp \left(-\frac{\dot{\varepsilon}_{2} / \dot{\varepsilon}_{1}-0.582}{2.60}\right)+ \\
& +1.97 \times \exp \left(-\frac{\dot{\varepsilon}_{2} / \dot{\varepsilon}_{1}-0.582}{27.6}\right)
\end{aligned}
$$

The results of the deformation resistance prediction for the investigated steel, under industrial hot rolling conditions, utilizing data from the laboratory plastometer experiments 
and equations (7-9) are shown in Figure 5. However, both (8) and (9) expressions describe only $p^{\prime}=p^{\prime}\left(T, \dot{\varepsilon}_{2} / \dot{\varepsilon}_{1}=\right.$ 10) and $p^{\prime}=p^{\prime}\left(T=1050^{\circ} \mathrm{C}, \dot{\varepsilon}_{2} / \dot{\varepsilon}_{1}\right)$, respectively. Lack of proper experimental data in whole temperature-strain rate range of service hot rolling restricts our prediction only to the stands where temperature of deformation are close to $T$ $=1050{ }^{\circ} \mathrm{C}$, i. e. the $4^{\text {th }}, 5^{\text {th }}$ and $6^{\text {th }}$ stands. Here the results are in good agreement with the peak stress value predictions described in Ref. [22] (see Figure 5.).

To predict correctly the stress values for the whole hot rolling process, it is necessary to perform more simple tests at temperatures covering the whole range of rolling temperatures with several different strain rates, but still lower than the industrial ones. In the case we operate with proper range of plastometer ST data, the functional dependence of strain rate can be expressed in the form $p^{\prime}=p^{\prime}(T$, $\left.\dot{\varepsilon}_{2} / \dot{\varepsilon}_{1}\right)$. Utilizing this dependence, equation (7) and laboratory plastometer data, the value of MFS in the rolling mill can be predicted with fairly good accuracy. Also it is necessary to take into account the fact that, due to the possibility of DRX during finish rolling, predicted values in this region are the upper limit of the mean stress value in the rolling mill.

\section{SUMMARY}

The work has shown that for the prediction of stress values in service hot rolling condition, utilizing data from laboratory plastometer experiments, the following equation is adequate:

$$
\bar{\sigma}_{\text {mill }}=\bar{\sigma}_{l a b}\left(\frac{\dot{\varepsilon}_{m i l l}}{\dot{\varepsilon}_{l a b}}\right)^{p^{\prime} T}
$$

where $p^{\prime}$ functionally depends on $T$ and $\dot{\varepsilon}_{\text {mill }} / \dot{\varepsilon}_{\text {lab }}$.

\section{REFERENCES}

[1] J. Boruta, I. Schindler, P. Szturc, M. Liska: In Proc HSLA Steels'95. Beijing: China, (1995), 367

[2] S. H. Cho, K. B. Kang, J. J. Jonas: ISIJ Int (2001), 41, 766

[3] S. F. Medina, A. Quispe: ISIJ Int (2001), 41, 774

[4] S. F. Medina, C. A. Hernandez: Acta Mater (1996), 44, 165

[5] R. Abad, B. Lopez, I. Gutierrez: Mater Sci Forum (1998), $284-$ 286, 167

[6] H. L. Andrade, M. G. Akben, J. J. Jonas: Metall Trans A (1983), 14A, (1967)

[7] E. I. Poliak, J. J. Jonas: Acta Mater (1996), 44, 127

[8] E. V. Pereloma, B. R. Crawford, P. D. Hodgson: In Proc $7^{\text {th }}$ Int Symp Physical Simulation. Tsukuba: Japan, (1997), 185

[9] L. P. Karjalainen: Mater Sci Technol (1995), 11, 557

[10] L. P. Karjalainen, J. Perttula, Y. Xu, J. Niu: In Proc $7^{\text {th }}$ Int Symp Physical Simulation. Tsukuba: Japan, (1997), 231

[11] J. J. Jonas, W. J. Liu: Metall Trans A (1988), 19A, 1403

[12] D. Q. Bai, S. Yue, J. J. Jonas: In Proc $1^{\text {st }}$ Int Conf Modelling Metal Rolling Processes. London: UK, (1993), 180

[13] J. J. Jonas: Mater Sci Forum (1998), 284-286, 3

[14] P. R. Cetlin, S. Yue, J. J. Jonas, T. M. Maccagno: Metall Trans A (1993), 24A, 1543

[15] T. M. Maccagno, J. J. Jonas: ISIJ Int (1994), 34, 607

[16] E. Anelli: ISIJ Int (1991), 32, 440

[17] Y. Saito: Trans ISIJ (1987), 27, 419

[18] V. I. Zyuzin, M. Ya. Brovma, A. F. Melnikov: Steel deformation resistance during hot rolling (in Russian). Moscow: Metallurgiya, (1964)

[19] I. Schindler, J. Kliber, J. Boruta: In Proc $7^{\text {th }}$ Int Symp Physical Simulation. Tsukuba: Japan, (1997), 417

[20] T. Kvackaj: Acta Metall Slovaca (1999), 5, 329

[21] M. Dzubinsky, F. Kovac, J. Boruta: Acta Metall Slovaca (1999), 5,324

[22] S. F. Medina, C. A. Hernandez: Acta Mater (1996), 44, 137 